\title{
AGROFORESTRY SYSTEMS IN POLAND A PRELIMINARY IDENTIFICATION
}

\author{
ROBERT BOREK \\ Institute of Soil Science and Plant Cultivation - State Research Institute \\ 24-100 Puławy, Czartoryskich 8, Poland \\ e-mail: rborek@iung.pulawy.pl \\ European Agroforestry Federation (EURAF), 34070 Montpellier, \\ 14 Rue Pagès, France
}

\begin{abstract}
This paper seeks to use state-of-the-art knowledge to depict the foundations and prospects for agroforestry systems in Poland to develop, in line with political, legal, historical and environmental conditions pertaining in the country. The main legal provisions concerning the presence of trees in agriculture are presented prior to a first-ever defining of key traditional agroforestry systems in Poland.
\end{abstract}

KEY WORDS: agroforestry, sustainable agriculture, GHG mitigation, strategies for adapting to climate change, farming systems, biodiversity, shelterbelts, woodlands.

\section{INTRODUCTION}

Agriculture is a sector of the economy directly dependent on weather conditions and very sensitive to small variations in climate. Hence, where agriculture is concerned, climate change will have impacts both positive (a longer growing seasons and higher temperatures) and negative (a water deficit, increased frequency of flooding, increased variability of temperature and precipitation, and changes in the occurrence of pests and diseases) - see SPA... 2013). Given the vulnerability of agriculture, experts groups working for the European Commission promote use two narratives to improve 
productivity while enhancing natural resources and addressing environmental concerns (Freibauer et al. 2011). On the one hand, research seeks to identify and develop farming techniques that can improve specific aspects of sustainability. On the other, stress is placed on holistic and systems-based approaches to the generation and sharing of knowledge. The second approach is based on the design of faming systems that balance the various dimensions to sustainability from the outset. Systems could include those with higher dual contributions, i.e., to both food production and objectives involving bioenergy, landscape and biodiversity values. Moreover, low-input farming systems should be promoted and pursued with a view to drivers of biodiversity change being mitigated and adaptive management strategies as regards climate change developed (Freibauer et al. 2011, SCAR 2012).

The presence of trees and shrubs helps buffer annual food crops from climatic variability as regards a number of local conditions, with these ranging from semi-natural elements on croplands and grasslands, through shelterbelts, to the design of modern agroforestry systems like alley cropping systems in which standard trees, fruit/nut trees or coppice systems are grown in rows between annual crops or pasture (Manning et al. 2009, Smith et al. 2012, Smith et al. 2013, Hartel et al. 2013). The benefits of trees on farms include: biomass production (Mantau and Saal 2010, Grünewald et al. 2007), soil health (Schroth, Sinclair 2003), carbon storage (Kumar, Nair 2011), erosion control (Palma et al. 2007), microclimate regulation (Kędziora et al. 2002) and the prevention of leaching (Ryszkowski and Kędziora 2007). Compared with conventional systems based on large-scale crop monocultures, agroforestry systems are believed to enhance the provision of ecosystem services, including higher productivity of crops (Jose 2009, Tsonkova et al. 2012, Graves et al. 2007) as well as giving rise to increased variety of wildlife species that might impact upon the natural control of pests or pollination (Jose 2009). The benefits for farmers depend on tree-crop interaction, and the adaptation of the system to local economic, social and environmental conditions. Agroforestry is prioritised in Europe as one of the five sustainable farming systems in the report prepared for the European Parliament's Science and Technology Options Assessment Panel-STOA (Underwood et al. 2013), and mentioned as sustainable land management practice in the last report of the IPCC (Smith et al. 2014). It is also part of the agenda of the Global Research Alliance on Agricultural Greenhouse Gases (GRA).

The total technical potential for soil carbon sequestration through agroforestry in the EU-27 was an estimated 1566 million tonnes $\mathrm{CO}_{2}$-equivalent per year. This corresponds to $37 \%$ of all $\mathrm{CO}_{2}$-equivalent emissions in the EU in 2007 (Aertsens et al. 2013). However, despite such enormous potential benefits, the systems combing trees and crops on the same land remain under-recognised in terms of their being climatechange mitigation and adaptation measures in agriculture. This is particularly evident in Europe, where studies of innovative modern agroforestry systems were only initiated two decades ago (EURAF 2015), not with standing the existence of methods to integrate trees and agriculture that have been practised here for thousands of years. Agroforestry definition and agroforestry regional policy need to be clarified in the light of a transition 
of the systems present in Poland that has taken place in recent times. If these issues are addressed to decision-makers, a decline in biodiversity-supporting ecosystem services might be averted, and the design of modern agroforestry systems in Poland promoted.

\section{AGROFORESTRY IN THE CONTEXT OF POLISH CONDITIONS}

Agroforestry systems include both traditional and modern land-use systems in which trees are managed together with crops and/or animal production systems in agricultural settings. EURAF states that the term "agroforestry" means land-use systems and practices in which woody perennials are deliberately integrated with crops and/or animals on the same land management unit. The trees may be single or in groups inside parcels (silvoarable agroforestry, silvopastoralism, grazed or intercropped orchards) or on the limits between parcels (hedges and tree lines). Mosquera-Losada et al. (2009) identified agroforestry practices within Europe (Tab. 1), it being noteworthy in this regard that certain practices included in the classification (like improved fallow) are unlikely to be present in Poland, while others might not even be permitted.

In turn, the definition of agroforestry adopted in the EU's 2005 Council Regulation (2005) on support for rural development by the European Agricultural Fund for Rural Development (EAFRD) is as follows: "Agro-forestry system" shall mean land-use systems in which trees are grown in combination with extensive agriculture on the same land. The maximum number of trees to be planted per hectare shall be determined by

Table 1. Agroforestry practices in Europe

\begin{tabular}{|l|l|}
\hline \multicolumn{1}{|c|}{ Agroforestry practice } & \multicolumn{1}{c|}{ Brief description } \\
\hline Silvoarable agroforestry & $\begin{array}{l}\text { Widely-spaced trees intercropped with annual or perennial crops. } \\
\text { Comprises alley cropping, scattered trees and line belts. }\end{array}$ \\
\hline Forest farming & $\begin{array}{l}\text { Forested areas used for production or harvest of natural standing } \\
\text { speciality crops for medicinal, ornamental or culinary uses. }\end{array}$ \\
\hline Riparian buffer strips & $\begin{array}{l}\text { Strips of perennial vegetation (tree/shrub/grass) natural or planted } \\
\text { between croplands/pastures and water sources such as streams, lakes, } \\
\text { wetlands and ponds to protect water quality. }\end{array}$ \\
\hline Improved fallow & $\begin{array}{l}\text { Fast-growing, preferably leguminous woody species planted during the } \\
\text { fallow phase of shifting cultivation; the woody species improve soil } \\
\text { fertility and may yield economic products. }\end{array}$ \\
\hline Multipurpose trees & $\begin{array}{l}\text { Fruit and other trees randomly or systematically planted on cropland } \\
\text { or pasture for the purpose of providing fruit, fuelwood, fodder and } \\
\text { timber, amongst other services, on farms and rangelands. }\end{array}$ \\
\hline Silvopasture & $\begin{array}{l}\text { Combining trees with forage and animal production. Comprises forest } \\
\text { or woodland grazing and open forest trees. }\end{array}$ \\
\hline
\end{tabular}

Source: Mosquera-Losada et al. 2009. 
the Member States taking account of local pedo-climatic conditions, forestry species and the need to ensure agricultural use of the land. Many Member States have likewise implemented Article 23 of a 2013 EU Regulation establishing rules for direct payments to farmers, which deliver support for the establishment and maintenance of agroforestry systems. However, this has not been implemented in Poland. The maximum number of trees per ha on Polish farms eligible for direct subsidies within the period 20152020 is determined at 100 trees, in compliance with the limit set by EC Delegated Regulation (2014a). Further considerations on the eligibility of parcels with trees are as outlined below.

There is an inseparable link between the development of agroforestry in Poland and political and social transformations of the agricultural economy. After World War II, "Green Revolution" agriculture focused on the goal of intensifying food production through the increased use of various technologies and inputs. This resulted in a decline in traditional agroforestry systems in Europe, caused mainly by increased mechanisation leading to the removal of trees, the maximisation of productivity through monocultures, a reduction in the agricultural work force limiting the viability of labourintensive systems, farm consolidation, a favouring of single-crop systems by the Common Agricultural Policy (CAP) and the ineligibility of wooded areas for subsidy payments (Eichhorn et al. 2006). In contrast to Western Europe, the post-communist countries of Central and Eastern Europe had their farmland affected in a different way. The collectivisation policy merged small farms into large-scale industrial ones, though the process often proved relatively in efficient due to strong opposition on the part of farmers that resulted in many abandoned patches of semi-natural land. There is a predominance of subsistence and semi-subsistence farming, which often contributes to biodiversity via mosaic low-intensity farmland, and is an integral part of High Natural Value farming (Davidova et al. 2013, Oppermann et al. 2012). Such farmland structure is present over a large part of Poland's rural areas- particularly in the south and east - and is characterised by small farms with plot fragmentation and low-intensity management that stands in marked contrast to the intensive farming systems of northern and western Poland. Further considerations on agrarian land-use structure in the context of agroforestry can be found in the paper by Woch and Borek (this issue).

At the same time, from the forestry point of view, Polish forests made subject to a steady process of nationalisation between the First and Second World Wars, came to be a sustainably-managed and multifunctional element of the landscape of Poland, as opposed to many other European countries. The State Forests National Forest Holding was founded in 1924. Soon after the Second World War's end - still in 1945 - the borders of Poland were set by the victorious powers and shown to encompass a forest cover equal to just 20.8\%. From 1945 to 1970, reafforestation within these new borders of Poland encompassed 1 million ha of land, taking the forest cover in Poland back up to $27 \%$ by the end of the period (Fronczak 2013). Presently, with a figure of $31 \%$ (Leśnictwo... 2014), Poland is among countries with the highest percentage forest cover 
in Europe. $81 \%$ of the 8.7 million ha are state-owned forest, while the remaining $19 \%$ is in private hands (this mainly being located in the east and south). A characteristic of forests owned by the state is that they are accessible to the public. The National Programme for the Augmentation of Forest Cover (1995) assumes a further increase of the forested area to $33 \%$ by 2050 . Areas with trees and shrubs outside forests are considered the basis for this increase (Krajowy... 1995).

In Poland, the introduction and management of trees and shrubs in the agricultural landscape is considered an important element of afforestation activity as set out in the State Forestry Policy (1997) and the State Ecological Policy (2000). In the second case, midfield trees and shrubs and buffer strips along watercourses are considered among the main priorities where protection of the land surface is concerned, on a par with good agricultural practices (Polityka... 1997, Polityka... 2000).

The next policy paper on environment protection in Poland - the National Strategy on Conservation and the Sustainable Use of Biodiversity (2007) recommends creating favourable conditions for the regeneration of ecological corridors and an increase in the area of wooded land (including land planted with trees and bushes) in farming areas (Krajowa... 2007). Last but not least, the Polish National Strategy for Adaptation to Climate Change by 2020 with a Perspective to 2030 (SPA... 2013) highlights the need to support on-farm investment and technological advisory services, including aspects of the adaptation of methods of agricultural production to climate change and support for them. Among the planned actions in agriculture, three (a change in farming systems, the prevention of soil degradation and crop diversification) are consistent with opportunities concerning agroforestry systems. Futhermore, areas of afforestation on farmland are protected within the borders of NATURA 2000 areas, National Parks, Landscape Parks, Protected Landscape Areas as well as within borders of ecolands (Ustawa o ochronie przyrody... 2004).

There is a great discrepancy between wording that defines woodlots or areas of scattered trees and shrubs outside forests in different instruments of Polish law. Under the Nature Protection Act (2004), woodlots are "trees and shrubs along road strips; and scattered trees and shrubs or clusters thereof, to be deemed forest within the meaning of the Act on Forests and which include the land occupied by them and remaining components of plant cover that meet productive, protective and sociocultural objectives". Forests, forest lands, non-forest lands designated for afforestation, orchards, plantations, nurseries of trees and shrubs and designed green areas in cities and residential estates are not included here (Ustawa o ochronie przyrody... 2004, Ustawa o lasach... 1991). The MRDC Regulation from 2001 lays down definitions of "lands covered with trees and shrubs". They are defined as "lands including those covered in forest vegetation, of areas less than $0.1 \mathrm{ha}$, and the following lands: midfield clusters of trees and shrubs not classified as forest; peatlands partially covered with clusters of shrubs and dwarf trees; land covered by natural vegetation of wicker willows and osiers in river valleys and local depressions; land covered with trees and shrubs adjacent to surface waters and performing the function of buffer strips; ravines 
and gorges covered with trees and shrubs naturally or artificially in order to protect against erosion and not classified as forest; piles of stones and areas covered with ruins where there is a cover of trees and shrubs; abandoned sites of cemeteries supporting trees and shrubs; clusters of trees and shrubs outside forest complexes performing the recreational function of a park but not equipped with buildings and structures serving leisure and recreation" (Author's translation). The definition does not make it sufficiently clear how large the area of land covered by trees and shrubs concerned should be. The Nature Protection Act and the MRDC Regulation (2001) also concern ecological sites/sites of ecological interests - this type of land use including remnants of an ecosystem significant for biodiversity conservation, with the establishment of the site being based on the regulations of local administrative units. The sites include clusters of trees and shrubs. Woodlots are not considered in the land-use categories other than those listed in the MRDC Regulation (2001). This means a lack of unified, consistently-used terminological references in legal acts pertaining to woodlots and scattered trees and shrubs outside forest (Sitarski 2011).

Moreover, where trees and shrubs outside forests are concerned, the Polish legal acts are focused rather on individuals. In principle, cutting down trees (except forests) is prohibited by the Nature Protection Act. However, the law provides derogations from that prohibition in the case of trees younger than 10 years, or fruit trees, or when a permit for felling is issued on the basis of an administrative decision. In other cases, such activities might lead to the imposition of major fines, unless the accused person is able to prove that he has planted substitute trees on the parcel of land. Pruning is allowed in the case of damaged branches or those resulting in technical conflicts, where trees are less than 10 years old, or with a view to the crown of a tree being adjusted.

Where woodlots are concerned, local councils shall be obliged to establish and maintain them, however existing legislation makes it difficult to take them into consideration as local spatial development plans, studies of conditions and directions to spatial development in gminas or Environmental Impact Assessment reports at the level of units of local administration are drawn up.

In principle, direct support schemes under the CAP are linked to cross-compliance rules relating to basic standards concerning the environment, food safety, animal and plant health and animal welfare (Statutory Management Requirements - SMR), as well as the requirement that land be maintained in Good Agricultural and Environmental Condition (GAEC). The SMR inter alia concerns, the prohibition of the destruction of places enjoying protection under the Habitats Directive and Birds Directive. As regards CAP implementation for the period 2015-2020, the most important GAEC for agroforestry (and the only one relevant in Poland) is GAEC-7 (Retention of landscape features, including where appropriate, hedges, ponds, ditches, trees in line, in group or isolated, field margins and terraces, and including a ban on cutting hedges and trees during the bird breeding and rearing season). Hedges and strips of trees within an agricultural parcel are embraced by the measure (except willows, fruit trees and 
short-rotation coppice). These may not be cut between $15^{\text {th }}$ April and $21^{\text {st }}$ July. Trees enjoying Monument of Nature status must not be damaged. "An agricultural parcel that contains these scattered trees shall be considered as eligible area provided that the following conditions are fulfilled: (a) agricultural activities can be carried out in a similar way as on parcels without trees in the same area; and (b) the number of trees per hectare does not exceed a maximum density" [in Poland 100 trees ha-1-author's comment] (EC Delegated Regulation, 2014a, Art. 9, point 3).

In order for environmental impacts to be reduced, the European Commission has also proposed - within the CAP 2015-2020 framework - a number of 'greening measures' that include obligatory crop rotation, grassland maintenance, and more specific agri-environment measures, aimed at climate change mitigation and biodiversity conservation and brought together under the umbrella concept of Ecological Focus Areas (EFA). "Where the arable land of a holding covers more than 15 hectares, the farmer shall ensure that, from 1 January 2015, an area corresponding to at least 5\% of the arable land of the holding that the farmer declared [...] and, if they are considered to be ecological focus area by the Member State [...] is Ecological Focus Area. The percentage referred to in the first subparagraph of this paragraph shall be increased from 5\% to $7 \%$ subject to a legislative act of the European Parliament and of the Council [...]" (EU Regulation 2013, Article 46, point 1). As regards land features and areas including trees that are listed as EFAs and adopted in Poland these are: areas with short-rotation coppice (willow, birch and black poplar and its hybrids - harvested over rotation cycles of not more than 8 years for willow and poplar and 10 years for birch; with a rate of NPK fertilizer use not greater than 20:20:40 kg ha hear-1 $^{-1}$ and 80:30:80 $\mathrm{kg} \mathrm{ha}^{-1}$ year-1 $^{-1}$ in the establishment year and in the year following the harvest, respectively; without the use of chemical plant protection products), afforested areas which in 2008 gave the right to payments under the Single Area Payment System (SAPS) scheme, riparian buffers (including strips with riparian vegetation of widths up to 10 metres) and landscape features such as hedges or wooded strips, isolated trees, trees in lines and trees in groups (based on criteria set out in Article 45 of EC Regulation, 2014b).

\section{PRELIMINARY IDENTIFICATION OF AGROFORESTRY SYSTEMS}

In the context of the development of agroforestry in Poland, it is acknowledged that trees fall within three main functional categories, as protective, productive or social-cultural (Zajączkowski et al. 2001). Lasting recent decades, the protective functions of trees have gradually come to be recognised in the Polish literature as the ones most important for the agricultural landscape (Ryszkowski et al. 2002, Kędziora 2011). Particular attention is paid to the roles of lines of woody vegetation (shelterbelts, hedgerows) and woodlands in: enhancing local water balance (Ryszkowski and Kędziora 1987), preventing water and wind erosion (Węgorek 1997), protecting water 
quality (Ryszkowski and Kędziora 2007) and preserving and enhancing biodiversity (Ryszkowski et al. 2002). Polish studies have thus contributed significantly to a better understanding of the functionality of Europe's trees beyond forests. This has also had implications for the EU environmental policy-making process, in particular CAP policy, where the rules on management of the agricultural landscape were included gradually.

However, the majority of Polish scientific works have been published in nativelanguage or regional journals, to the extent that their presence has long gone undetected by the international community. As Sutcliffe et al. (2014) recently noted, under-representation of the low-intensity farmland of Central and Eastern Europe in the international literature and CAP is impeding the development of sound, evidence-based conservation measures.

Many regions within Poland are still characterised by high-biodiversity farmland, usually with a large number of trees present. Agricultural land is often surrounded by riparian buffers along watercourses and lakes. Shelterbelts and scattered trees on farmland and even small woodlots are found commonly in many areas. The fragmented structure of farms and diverse topography favour the presence of small groups of trees on agricultural land, especially in the central and eastern parts of Poland, e.g. Suwałki Landscape Park, the Roztocze Uplands or the Low Beskid Mountains.

The development of traditional agroforestry also occurred in line with historical circumstances of given regions. Shelterbelts and alley trees were actively introduced to Polish agriculture actively by public authorities. One well-known example is the Żuławy Gdańskie marshland. The first registered planting of alley trees in this agricultural region dates back to the $16^{\text {th }}$ century. Also noteworthy are the 300 shelterbelts of total length $270 \mathrm{~km}$ established in the 1960s. Nowadays, planting activities in this area are performed by employees of the Vistula Spit Landscape Park, and by local organizations. Another well-known example is the landscape around Turew in Wielkopolska, created by Dezydery Chlapowski at the beginning of the $19^{\text {th }}$ century. Chlapowski transformed 10000 hectares, of very much monotonous landscape into a mosaic with woody patches, shelterbelts, tree lines and bodies of water. These newly-created structures were intended as a source of hardwood for farmers, a nutritional source for bees and a shelter area for domestic animals, crops and soil. The Institute for the Agricultural and Forest Environment of the Polish Academy of Sciences has been investigating the functions of these structures since the 1950s. In addition, the Institute has created $100 \mathrm{~km}$ of new shelterbelts and 10 hectares of woody patches. Among other results, the Institute's research work shows that the woody structures in the Turew area reduce diffuse pollution in ground water, improve the microclimate for crops, increase biological diversity and ameliorate the water supply. In accordance with these principles, a network structure with woody corridors and nodes is promoted in agricultural landscape (Zajączkowski 2005).

Planting and cultivation rules for groups of trees and shrubs in the agricultural landscape in relation to local conditions were developed by researchers of the Forest 
Research Institute in Sękocin (Zajączkowski 2005, Zajączkowski J., Zajączkowski K. 2009), researchers of the Institute for the Agricultural and Forest Environment of the Polish Academy of Sciences in Poznań (Ryszkowski et al. 2002) and scientists of Institute of Soil Science and Plant Cultivation - State Research Institute in Puławy and of Agricultural Academy in Lublin (Tałałaj 1997, Węgorek 1997). The introduction of shelterbelts and woodlots is regarded as fully compliant with the division of Poland into physio-geographic regions and habitat requirements, and depends on the desired function (wind-breaking, restricting soil erosion by water, biocoenotic, productive, aesthetic, etc.). Hence, recommendations are linked closely with the rational management of the agricultural landscape, but also suggests which form of afforestation (e.g. group, row or strip) or which species composition should be applied in given conditions.

In contrast to arable landcomprising biodiversity-rich and pest-control field margins often including lines or strips of trees, trees and shrubs are usually an integral part of grasslands and pasturelands. A majority of the areas have a high proportion of semi-natural vegetation and qualify as farmland of Type 1 High Natural Value. Silvopastoral agroforestry systems remain common today in the valleys of rivers, like the Vistula, Biebrza, Narew, Warta, Bug and Wieprz. These semi-natural ecosystems are usually grazed or mown. Pastures with pollarded willows (Salix alba, Salix fragilis) were widespread in the past, but for several decades now the area has decreased steadily, due to labour-intensive pollarding and a decline in numbers of cattle. Remaining areas can still be found, especially in lowlands, e.g. the Mazovian Lowland, Żuławy Wiślane (within the Vistula Delta), or along river valleys. The willows provide shade and fodder for animals; at the same time offering habitat to a great variety of insects and birds, e.g. hermit beetles, bumblebees, little owls and hoopoes.

Pastoral use of forest areas is not permitted in Poland. However, under the supervision of the State Forest Inspectorate in Strzałowo in Poland's North-East, trials are ongoing with Polish horses from the Biłgoraj region. The horses graze in a thermophilous oak forest in order to restore ecosystem biodiversity.

Down the centuries, more than a thousand varieties of apple and other fruit trees have been grown on grasslands in Poland. Unfortunately, many orchards have disappeared over the last century, while others have been abandoned. With the beginning of the $20^{\text {th }}$ century, a number of tree nurseries were established, these reflecting a growing interest in the saving and protecting of traditional orchard varieties. Several Polish research units are engaged in establishing collections of local varieties, as well through gene-bank initiatives seeking to preserve local biodiversity, e.g. the Research Institute of Horticulture in Skierniewice, the Botanical Garden of the Polish Academy of Science in Warsaw, the Arboretum in Bolestraszyce and others. The replanting of old varieties is also supported by a variety of Polish NGO's and Landscape Parks, e.g. the Chełmiński and Nadwiślański Landscape Park along the Vistula River Valley, the Łódź Hills Landscape Park, Wigry National Park, and a number of parks in mountain areas of southern Poland. 
The dispersion of both agroforestry systems and the knowledge about them hampers the introduction of protective measures, and is a major reason why hectares embraced by agroforestry remain unlisted as Polish Ecological Focus Areas. The development and implementation of modern agroforestry systems is in turn blocked at the level of legislative acts, which fail to take account of the groups of trees present on farmland. Some farmers voluntarily plant mid-field trees or shrubs, in this way introducing innovative adaptive activities encouraging resilience to climate change. There is a need to integrate and support environmental and social policies within this field on a national and local scale.

\section{CONCLUSIONS}

This short overview does not identify all factors in the development of agroforestry systems that are present on Polish territory. The systems vary markedly, depending on local conditions and farmers' perception of the functionality of trees (inclusive of the provision of additional income) on farmland. Applicable legislation not only does not support, but even impedes, the implementation of treeplanting on farms, including shelterbelts and modern agroforestry systems. This is contrary to the dominant trend in European policies towards sustainable intensification of agriculture that is stressing the importance of climate change-resilient cropping systems for farmers linking climate-change mitigation and adaptation. In particular, farming activities should be consistent with Polish National Strategy for Adaptation to Climate Change by 2020 within a Perspective to2030 (SPA... 2013) within the framework of the EU Strategy on Adaptation to Climate Change (EU Strategy 2013). Despite the prioritising of agroforestry by experts from EURAF, STOA, the IPCC and GRA, there is a lack of knowledge on this. As Schoeneberger (2008) noted, reasons for agroforestry measures to go unrecognised include the limited information-base and number of tools agroforestry can currently offer as compared with what has been generated by decades of investment in agriculture and forestry, as well as a cross-cutting nature that reflects agroforestry's place at the interface between agriculture and forestry, where it is not strongly supported or promoted by either. It would therefore seem very necessary for agroforestry to be viewed as something separate from both of these other disciplines.

\section{ACKNOWLEDGEMENTS}

I am grateful for the support of colleagues in the European Agroforestry Federation (EURAF). My special thanks also go out to colleagues who helped me organize the First Polish Agroforestry Conference held on 25th November 2014 at Puławy at the IUNG-PIB, which resulted in this paper. 


\section{REFERENCES}

Aertsens J., De Nocker L., Gobin A., 2013, Valuing the carbon-sequestration potential for European agriculture, Land Use Policy, 31, 584-594.

Davidova S., Bailey A., Dwyer J., Erjavec E., Gorton M., Thomson K., 2013, Semi-subsistence farming - value and directions of development, Study prepared for the European Parliament Committee on Agriculture and Rural Development, Brussels, www.europarl.europa.eu/ committees/en/AGRI/studiesdownload.html?languageDocument=EN\&file $=93390$

EC Delegated Regulation, 2014a, Commission Delegated Regulation (EU) No 640/2014 of 11 March 2014 supplementing Regulation (EU) No 1306/2013 of the European Parliament and of the Council with regard to the integrated administration and control system and conditions for refusal or withdrawal of payments and administrative penalties applicable to direct payments, rural development support and cross compliance, http://eurlex.europa.eu/ legal-content/en/TXT/?uri=CELEX:32014R0640

EC Delegated Regulation, 2014 b, Commission Delegated Regulation (EU) 639/2014 of 11 March 2014 supplementing Regulation (EU) No 1307/2013 of the European Parliament and of the Council establishing rules for direct payments to farmers under support schemes within the framework of the common agricultural policy and amending Annex $X$ to that Regulation, http://eurlex.europa.eu/legalcontent/EN/TXT/?uri=OJ:L:2014:181:TOC

Eichhorn M. P., Paris P., Herzog F., Incoll L. D., Liagre F., Mantzanas K., Mayus M., Moreno G., Papanastis V.P., Pilbeam D.J., Pisanelli A., Dupraz C., 2006, Silvoarable systems in Europepast, present and future prospects, Agroforestry Systems, 67, 1, 29-50.

EU Council Regulation, 2005, European Council Regulation No. 1698/2005 of 20 September 2005 on support for rural development by the European Agricultural Fund for Rural Development (EAFRD), http://eurlex.europa.eu/legalcontent/en/ALL/?uri=CELEX:32005R1698

EU Regulation, 2013, Regulation No. 1307/2013 of the European Parliament and of the Council of 17 December 2013 establishing rules for direct payments to farmers under support schemes within the framework of the common agricultural policy and repealing Council Regulation (EC) No 637/2008 and Council Regulation (EC) No 73/2009.

EU Strategy, 2013, Communication from the Commission to the European Parliament, the Council, the European Economic and Social Committee and the Committee of the Regions, No. 216, EU Strategy on adaptation to climate change.

EURAF, European Agroforestry Federation, Available, 2015, http://www.agroforestry.eu

Freibauer A., Mathijs E., Brunori G., Damianova Z., Faroult E., Girona I., Gomis J., O’Brien L., Treyer S., 2011, Sustainable food consumption and production in a resource-constrained world, The Third Standing Committee on Agricultural Research Foresight Expert Group, February, 2011, http://ec.europa.eu/research/agriculture/scar/pdf/scar_feg_ultimate_version.pdf

Fronczak K., 2013, Signs of the times, The state forests: past and present, The State Forests Information Centre, Warsaw, 77 pp.

Graves A. R., Burgess P. J., Palma J. H., Herzog F., Moreno G., Bertomeu M., Dupraz C., Liagre F., Keesman K., van der Werf W., Koeffemande Nooy A., van den Briel J. P., 2007, Development and application of bio-economic modelling to compare silvoarable, arable, and forestry systems in three European countries, Ecological Engineering, 29, 4, 434-449. 
Grünewald H., Brandt B. K., Schneider B. U., Bens O., Kendzia G., Hüttl R. F., 2007, Agroforestry systems for the production of woody biomass for energy transformation purposes, Ecological Engineering, 29, 4, 319-328.

Hartel T., Dorresteijn I., Klein C., Máthé O., Moga C. I., Öllerer K., Roellig M., von Wehrden H., Fischer J., 2013, Wood-pastures in a traditional rural region of Eastern Europe: Characteristics, management and status. Biological Conservation, 166, 267-275.

Jose S., 2009, Agroforestry for ecosystem services and environmental benefits: an overview, Agroforestry Systems, 76, 1, 1-10.

Kędziora A., 2011, Windbreak and shelterbelt function, [in:] Encyklopedia of Agrophysics, Springer, Dordrecht, 1000-1004.

Kędziora A., Olejnik J., Eulenstein F., 2002, Water balance in agricultural landscape and options for its management by change in plant cover structure of landscape, [in:] L. Ryszkowski (ed.), Agroecosystems Management, CRC Press, 57-110.

Krajowy program zwiększania lesistości, (National Programme for the Augmentation of Forest Cover), 1995, http://www.mos.gov.pl/artykul/326_lesnictwo/296_krajowy_program_zwiek szania_lesistosci.html

Kumar B. M., Nair P. R., (eds), 2011, Carbon sequestration potential of agroforestry systems: opportunities and challenges, Springer Science \& Business Media, 307 pp.

Mantau U., Saal U., 2010, Material use, [in:] EUwood - Final report, Hamburg/Germany, 35-42.

Manning A. D., Gibbons P., Lindenmayer D. B., 2009, Scattered trees: a complementary strategy for facilitating adaptive responses to climate change in modified landscapes?, Journal of Applied Ecology, 46, 4, 915-919.

Mosquera-Losada M. R., McAdam J. H., Romero-Franco R., Santiago-Freijanes J. J., Rigueiro-Rodróguez A., 2009, Definitions and components of agroforestry practices in Europe, [in:] Rigueiro-Rodríguez A., McAdam J., Mosquera-Losada M. R., (eds), Agroforestry in Europe, Current Status and Future Prospects, Advances in Agroforestry, 6, Springer, Netherlands, 3-19.

MRDC Regulation, 2001, Rozporzadzenie Ministra Rozwoju Regionalnego i Budownictwa $z$ dnia 29 marca 2001 w sprawie ewidencji gruntów I budynków, (Regulation on the Land and Building Register of Ministry for Regional Development and Construction of 29 March 2001), Dziennik Ustaw, numer 38, pozycja 454, (Journal of Laws, no. 38, item 454).

Krajowa strategia ochrony i zrównoważonego użytkowania różnorodności biologicznej wraz z Programem Działań na lata 2007-2013, (National Strategy on Conservation and Sustainable Use of Biodiversity), 2007, Uchwała Rady Ministrów nr 270/2007 z dnia 26 października 2007 r., (Regulation of Ministry number 270/2007 26 October 2007), http://biodiv.gdos.gov. $\mathrm{pl} /$ wdrazanie-konwencji/national-strategy-conservation-an sustainable-use-biodivesity-polish

Leśnictwo 2014, Informacje i Opracowania Statystyczne, 2014, (Forestry 2014, Statistical Information and Elaborations), Główny Urząd Statystyczny, (Central Statistical Office), Warsaw, http://stat.gov.pl

Oppermann R., Beaufoy G., Jones G., (eds), 2012, High nature value farming in Europe, Ubstadt-Weiher: Verlag Regionalkultur, 544 pp.

Palma J. H., Graves A. R., Bunce R. G. H., Burgess P. J., De Filippi R., Keesman K. J., van Keulen H., Liagre F., Mayus M., Moreno G., Reisner Y., Herzog F., 2007, Modeling 
environmental benefits of silvoarable agroforestry in Europe, Agriculture, Ecosystems \&Environment, 119, 3, 320-334.

Polityka Ekologiczna Państwa (State Ecological Policy), 2000, http://www.mos.gov.pl/ artykul/328_polityka_ekologiczna/338_polityka_ekologiczna_panstwa.html

Polityka Leśna Państwa (State Forestry Policy), 1997, Ministerstwo Ochrony Środowiska Zasobów Naturalnych i Leśnictwa, Warszawa http://www.mos.gov.pl/g2/big/2009_04/34b a398d45e363aed16d2ad3b015136a.pdf

Ryszkowski L., (ed.), 2002, Agroecosystems management, CRC Press, 384 pp.

Ryszkowski L., Karg J., Kujawa K., Gołdyn H., Arczyńska-Chudy E., 2002, Influence of landscape mosaic structures on diversity of wild plant and animal communities in agricultural landscape of Poland, [in:] L. Ryszkowski (ed.), Agroecosystems management, CRC Press, 697-713.

Ryszkowski L., Kędziora A., 1987, Impact of agricultural landscape structure on energy flow and water cycling, Landscape Ecology, 1, 2, 85-94.

Ryszkowski L., Kędziora A., 2007, Modification of water flows and nitrogen fluxes by shelterbelts, Ecological Engineering, 29, 4, 388-400.

SCAR (Standing Committee on Agricultural Research), 2012, Agricultural knowledge and innovation systems in transition - a reflection paper, Brussels, http://ec.europa.eu/research/ agriculture/scar/pdf/akis_web.pdf

Schoeneberger M. M., 2008, Agroforestry: working trees for sequestering carbon on agricultural lands, Agroforestry Systems, 75, 1, 27-37.

Schroth G., Sinclair F. L., (eds), 2003, Trees, crops, and soil fertility: concepts and research methods, CABI, 437 pp.

Sitarski M., 2011, Dlaczego należy zmienić definicje "zadrzewień” $i$ "terenów zieleni” w ustawie o ochronie przyrody, (Why the definitions of ,, woodlots" and ,green areas" in the Act on Protection of Nature should be changed), Człowiek i Środowisko, 35, 1/2, 93-106.

Smith J., Pearce B. D., Wolfe M. S., 2012, A European perspective for developing modern multifunctional agroforestry systems for sustainable intensification, Renewable Agriculture and Food Systems, 27, 4, 323-332.

Smith J., Pearce B. D., Wolfe M. S., 2013, Reconciling productivity with protection of the environment: Is temperate agroforestry the answer?, Renewable Agriculture and Food Systems, 28, 1, 80-92.

Smith P., Bustamante M., Ahammad H., Clark H., Dong H., Elsiddig E. A., Haberl H., Harper R., House J., Jafari M., Masera O., Mbow C., Ravindranath N. H., Rice C. W., Robledo Abad C., Romanovskaya A., Sperling F., Tubiello F., 2014, Agriculture, Forestry and Other Land Use (AFOLU), [in:] Climate Change 2014: Mitigation of Climate Change. Contribution of Working Group III to the Fifth Assessment Report of the Intergovernmental Panel on Climate Change, O. Edenhofer, R. Pichs-Madruga, Y. Sokona, E. Farahani, S. Kadner, K. Seyboth, A. Adler, I. Baum, S. Brunner, P. Eickemeier, B. Kriemann, J. Savolainen, S. Schlömer, C. von Stechow, T. Zwickel and J. C. Minx (eds), Cambridge University Press, Cambridge, United Kingdom and New York, NY, USA, 811-922.

SPA 2020, Polish National Strategy for Adaptation to Climate Change (NAS 2020) with the perspective by 2030, 2013, Ministry of the Environment Republic of Poland, Warsaw, https:// klimada.mos.gov.pl/wp-content/uploads/2014/12/ENG_SPA2020_final.pdf 
Stuczyński T., Kozyra J., Łopatka A., Siebielec G., Jadczyszyn J., Koza P., Doroszewski A., Wawer R., Nowocień E., 2007, Przyrodnicze uwarunkowania produkcji rolniczej w Polsce, (Natural conditions of agricultural production in Poland), Studia i Raporty IUNG-PIB, 7, $77-115$.

Sutcliffe L. M., Batáry P., Kormann U., Báldi A., Dicks L. V., Herzon I., Kleijn D., Tryjanowski P., Apostolova I., Arlettaz R., Aunins A., Aviron A., Baležentienė L., Fischer C., Halada L., Hartel T., Helm A., Hristov I., Jelaska S.D., Kaligarič M., Kamp J., Klimek S., Koorberg P., Kostiuková J., Kovács-Hostyánszki A., Kuemmerle T., Leuschner C., Lindborg R., Loos J., Maccherini S., Marja R., Máthé O., Paulini I., Proença V., Rey-Benayas J., Sans F.X., Seifert C., Stalenga J., Timaeus J., Török P., van Swaay C., Viik E., Tscharntke, T., 2014, Harnessing the biodiversity value of Central and Eastern European farmland, Diversity and Distributions, doi: 10.1111/ddi.12288.

Tałałaj Z., 1997, Wplyw zadrzewień na plonowanie roślin rolniczych, (The impact of afforestations on agricultural crops productivity), [in:] Znaczenie zadrzewień $w$ krajobrazie rolniczym oraz aktualne problemy ich rozwoju $w$ przyrodniczo-gospodarczych warunkach Polski, (The importance of farmland afforestations in agricultural landscape and the present problems of their introduction under natural and economic conditions of Poland), Matateriały Konferencyjne, Płock, (Proceedings of the Conference, Provincial Authority in Płock), 72-90.

Tsonkova P., Böhm C., Quinkenstein A., Freese D., 2012, Ecological benefits provided by alley cropping systems for production of woody biomass in the temperate region: a review, Agroforestry Systems, 85, 1, 133-152.

Underwood E., Poláková J., Berman S., Dooley E., Frelih-Larsen A., Kretschmer B., Maxted N., McConville A. J., Naumann S., Sarteel M.,Tostivint C., Tucker G.M., van der Grijp N., 2013, Technology options for feeding 10 billion people - Interactions between climate change \& agriculture and between biodiversity \& agriculture, Report prepared for STOA, the European Parliament Science and Technology Options Assessment Panel, Institute for European Environmental Policy together with BIO Intelligence Service, Ecologic Institute, IVM - VU University, http://eur-lex.europa.eu/legal-content/en/TXT/?uri= CELEX:32013R1307

Ustawa o lasach z dnia 8 września 1991, (Act on Forests of 28 September, 1991), Dziennik Ustaw numer 101 pozycja 44, (Journal of Laws number 101, item 44), http://isap.sejm.gov. pl/DetailsServlet?id=WDU19911010444

Ustawa o ochronie przyrody z dnia 16 kwietnia 2004, (Nature Protection Act of 16 March 2004), Dziennik Ustaw, numer 92, pozycja 880, (Journal of Laws, no. 92, item 880), http://isap. sejm.gov.pl/DetailsServlet?id=WDU20040920880

Węgorek T., 1997, Znaczenie zadrzewień w przeciwdziałaniu wodnej i wietrznej erozji gleby, (The importance of farmland afforestations in wind and water soil erosion control), [in:] Znaczenie zadrzewień $w$ krajobrazie rolniczym oraz aktualne problemy ich rozwoju w przyrodniczogospodarczych warunkach Polski, (The importance of farmland afforestations in agricultural landscape and the present problems of their introduction under natural and economic conditions of Poland), Matateriały Konferencyjne, Płock, (Proceedings of the Conference, Provincial Authority in Płock), 28-39. 
Zajączkowski K., 2005, Regionalizacja potrzeb zadrzewieniowych w Polsce, (Regionalization of agricultural landscape needs for shelterbelts and woodlots in Poland), Prace IBL, Rozprawy i Monografie, Papers of the Forest Research Institute, Dissertations and Monographs, Warszawa, 4, $127 \mathrm{pp}$.

Zajączkowski K., Tałałaj Z., Węgorek T., Zajączkowska B., 2001, Dobór drzew i krzewów do zadrzewień terenów wiejskich, (Trees and bushes selection for farmland afforestations), IBL, (Forestry Research Institute), Warszawa, 78 pp.

Zajączkowski J. and Zajączkowski K., 2009, Farmland afforestations: new goals and guidelines for Poland, Folia Forestalia Polonica, series A, 51, 1, 5-11. 